\title{
Phytochemical Screening and Antibacterial Assay of Radish Seed Oil on Selected Pathogenic Bacterial Species in Vitro
}

\author{
Nadia Khan ${ }^{1 *}$, Abdul Waheed ${ }^{1}$, Farrukh Siyar Hamid ${ }^{1}$, Naveed Ahmed ${ }^{1}$, Zafar Iqbal ${ }^{2}$, Seemab Ali $^{1}$, Madiha \\ Bashir $^{1}$ and Hina Gul ${ }^{3}$
}

${ }^{1}$ National Tea and High Value Crops Research Institute Shinkiari, Mansehra, Pakistan; ${ }^{2}$ Department of Agricultural Chemistry, The University of Agriculture Peshawar, Khyber Pakhtunkbwa, Pakistan; ${ }^{3}$ Department of Genetics, Hazara University Mansehra, Pakistan.

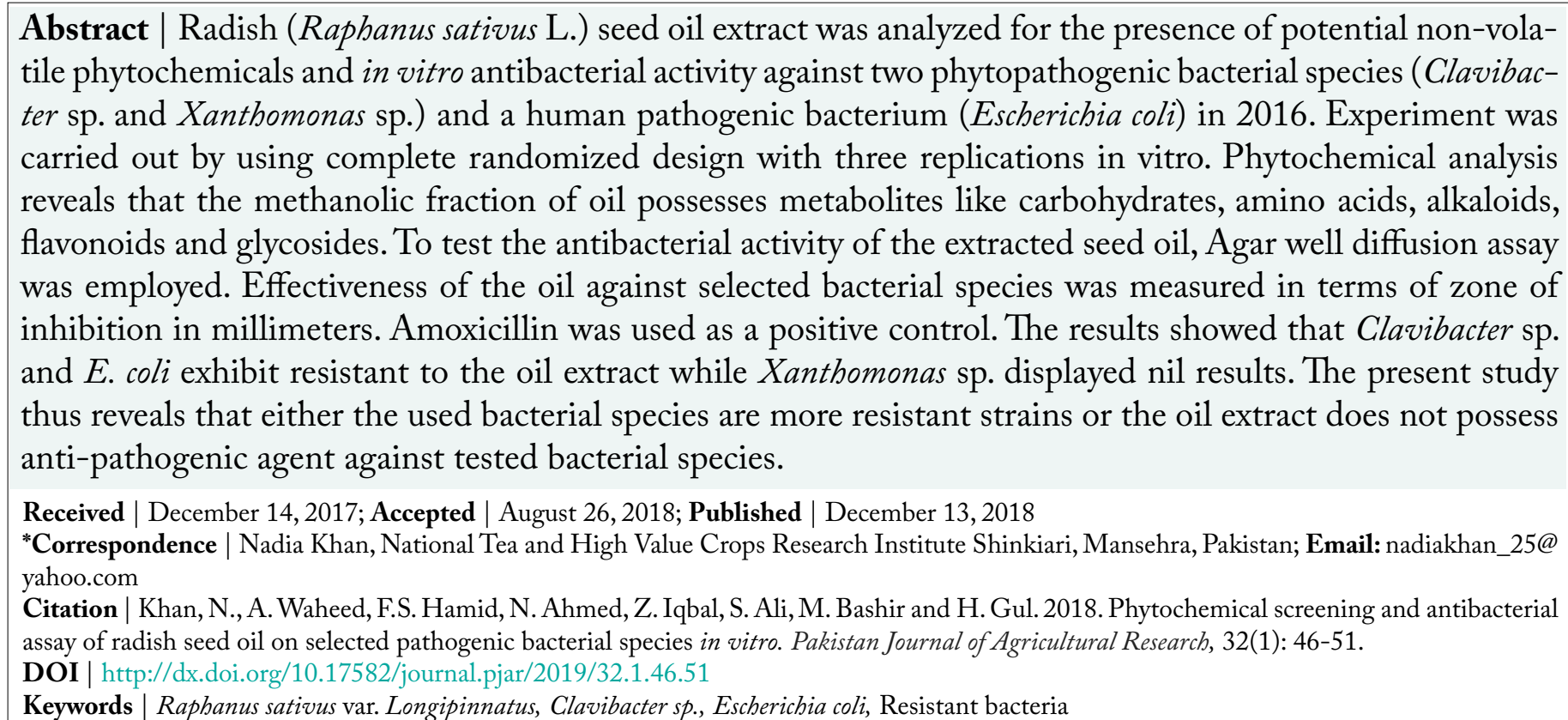

\section{Introduction}

$\mathrm{P}$ lants are a valuable source of phytochemicals refers to as secondary metabolites or natural products. These metabolites are identified to be useful in plant management and maintenance of human health, therefore could explain the use of plants extract as antimicrobial factor for prevention/treatment of several diseases in humans and other plants. Phytochemicals used for prevention or management of plant diseases are known as biochemical pesticides (Seiber et al., 2014). A renewed interest in plant based antimicrobials has arisen during the last twenty years, but still plant based antimicrobials are poorly explored.
Screening of plants extracts for antimicrobial activity has shown that Brassicaceae plants represent a potential source of anti-microbial compounds (Prasad et al., 2015). Radish, Raphanus sativus L. var. longipinnatus of Brassicaceae family is widely grown all over the world and its total yield per hectare in Pakistan is 16.41 tons (GoP, 2016). Extract of $R$. sativus is previously reported with a diverse range of metabolites with regard to biopharmaceuticals (Lugasi, 2005; Kim, 2011) and biopesticides (Javaid and Bashir, 2015). Aqueous extract of the whole plant is found potent against bacterial strains like Sarcina lutea and Staphylococcus epidermidis (Caceres, 1987). Parts of the 
plant; like leaves, roots and seeds have also been analyzed individually for antimicrobial activity and found active against many pathogens (Javaid and Bashir, 2015). Seeds of radish are rich source of chemical compounds like phenols, alkaloids, glycosides and sterols (Gutiérrez and Perez, 2004); these compounds are believed to potential against several pathogenic microbes (Candido, 2011). The main objective of this study is to assess non-volatile phytochemicals and antibacterial property of radish seed oil against selected bacterial species.

\section{Materials and Methods}

\section{Collection of radish seeds}

Radish seeds were collected from the fields of $\mathrm{Na}$ tional Tea and High Value Crops Research Institute (NTHRI), Shinkiari, in April 2016. Seeds were separated from stems and kernel manually and dried for 48 hours at $105^{\circ} \mathrm{C}$. The seeds were milled, sieved by particle size $(\mathrm{d}<0.4 \mathrm{~mm})$ and kept in a desiccators until use.

\section{Oil extraction from the seeds}

Oil from radish seeds was extracted with petroleum ether using Soxhlet apparatus. Powdered seeds sample of $10 \mathrm{mg}$ was loaded to thimble and placed into the extractor. Oil was extracted continuously for 8 hours with $35^{\circ} \mathrm{C}$ (Wang et al., 2011). After extraction, petroleum ether was evaporated by using rotary evaporator and crude was collected for antibacterial study. An amount of oil extract was mixed with equal amount of $10 \%$ aqueous methanol. After an hour a quiet immiscible layer of two solvents petroleum ether and methanol was formed. Aqueous methanolic fraction was collected and evaporated to crude formation for phytochemical tests.

\section{Collection of microbial culture and activity}

Microbial species used in the study were plant pathogenic bacteria including Clavibacter sp., and Xanthomonas specie and a human pathogenic bacteria Escherichia coli. The microbes were obtained from the Department of Agricultural Chemistry, University of Agriculture Peshawar, Pakistan. These microbial species were recultured using Luria Bertani (LB) broth at $37^{\circ} \mathrm{C}$ in incubator and maintained at $4^{\circ} \mathrm{C}$.

Screening of antibacterial assay was then carried out by well diffusion technique (Rojas et al. 2006). The potato dextrose agar (PDA) plates were seeded with $0.1 \mathrm{ml}$ of the recultured inoculum of each test organ- ism. The inoculum was evenly spread over PDA plates using a wire loop. A standard cork borer of $6 \mathrm{~mm}$ was used to cut uniform wells on the surface of the plate and $100 \mu \mathrm{L}$ radish seeds extract was introduced into the wells. Amoxicillin was used as a standard antibiotic agent. The inoculated plates were incubated at $37^{\circ} \mathrm{C}$ for 24 hours and zone of inhibition was measured in terms of millimeter $(\mathrm{mm})$.

\section{Proximate composition analysis}

Proximate moisture content and ash content was determined according to Association of analytical communities (AOAC) standard methods 950.46 and 942.05, repectively (Horwitz, 2000).

Moisture content: Empty dishes were pre-oven dried at $105{ }^{\circ} \mathrm{C}$ for $3 \mathrm{~h}$ and weighed. Add $3 \mathrm{gm}$ of radish seeds milled sample to the plate and oven dry at 105 ${ }^{\circ} \mathrm{C}$. After $3 \mathrm{~h}$, transfer the dishes to dessicator to cool. Reweight the sample along with dish. To calculate percent moisture content following formula was used;

$$
\text { Moisture content }=\frac{W_{1}-W_{2}}{W_{1}} \times 100
$$

\section{Where;}

$\mathrm{W}_{1}$ is weight of sample (g) before drying and $\mathrm{W}_{2}$ is weight of sample $(\mathrm{g})$ after drying

Ash content: Used crucibles were pre-heated overnight in furnace at $550{ }^{\circ} \mathrm{C}$ to burn off traces of impurities on its surface. The crucibles were weighed and 5 $\mathrm{g}$ of seeds sample were added to it. Place the sample containing crucibles in the furnace and heat overnight at $550{ }^{\circ} \mathrm{C}$. After $24 \mathrm{~h}$, transfer the crucibles to dessicator to let them cool. Reweight the sample and calculate percent ash content using following formula;

$$
\text { Ash content }(\%)=\frac{W_{2}}{W_{1}} \times 100
$$

\section{Where ;}

$\mathrm{W}_{1}$ is weight of sample $(\mathrm{g})$ before ashing and $\mathrm{W}_{2}$ is weight of sample (g) after ashing.

\section{Phytochemical screening}

Test for carbohydrates: Molisch test: About $1 \mathrm{~mL}$ of methanolic extract was treated with 2-3 drops of Molisch's reagent (10\% of 1-napthol in ethanol). The test tube was hold at an angle and 1-2 $\mathrm{mL}$ of conc. $\mathrm{H}_{2} \mathrm{SO}_{4}$ was added carefully along the sides of the test tube and observed for the formation of reddish violet ring at the junction (Trease and Evans, 1983). 
Test for amino acids: $2 \mathrm{~mL}$ of methanolic extract was treated with 2-5 drops of ninhydrin solution placed in a boiling water bath for 1-2 minutes and observed for the formation of purple colour.

Test for alkaloids: Mayer's reagent test: $1 \mathrm{~mL}$ of $1 \%$ $\mathrm{HCl}$ was added to $3 \mathrm{~mL}$ of methanolic extract in a test tube. The mixture was heated gently for $20 \mathrm{~min}-$ utes, allowed to cool and filtered. After this, two drops of Mayer's reagent were mixed in $1 \mathrm{~mL}$ of extract and observed for turbidity or creamy precipitates (Idu and Igeleke, 2012).

Test for polyphenols: Methanolic extract of 2-3 mL was treated with few drops of $10 \%$ aqueous $\mathrm{FeCl}_{3}$ and observed for the emergence of blue green colour (Trease and Evans, 1989; Sofowora, 1993).

Test for flavonoids: To $1 \mathrm{~mL}$ of methanolic extract, few drops of conc. $\mathrm{H}_{2} \mathrm{SO}_{4}$ were added along the sides of test tube. The formation of yellow colour indicated the presence of flavonoids (Trease and Evans, 1983; Idu and Igeleke, 2012).

Test for glycosides: Methanolic extract of $2.5 \mathrm{~mL}$ was treated with $5 \mathrm{~mL}$ of conc. $\mathrm{H}_{2} \mathrm{SO}_{4}$ and boiled for 15 minutes in water bath. This mixture was cooled and neutralised with $20 \% \mathrm{KOH}$. Three drops of $\mathrm{FeCl}_{3}$ was added to one half of the mixture and observed for green to black precipitates (Trease and Evans, 1983; Sofowora, 1993).

Test for tannins: $\mathrm{KOH}$ test: $1 \mathrm{~mL}$ of freshly prepared $10 \% \mathrm{KOH}$ was added to $1 \mathrm{~mL}$ of methanolic extract. Dirty white precipitates indicated the presence of tannins (Sofowora, 1993; Evans et al., 2002).

Test for saponins: Froth test: $2 \mathrm{~mL}$ of methanolic extract was taken in a test tube, shaken vigorously and observed for froth formation (Idu and Igeleke, 2012).

\section{Results and Discussion}

All the experimental treatments were performed in triplicates and analyzed statistically and observe at level of significance $\mathrm{P}>0.05$ of probability.

\section{Proximate composition analysis}

Radish seeds were found containing a high amount of oil content approximately $50 \%$ of total seeds weight. Sunflower seeds containing 40-45\% oil content and is known as one of the highest oilseeds plants (Martinez et al., 2015). Average 4.03\% methanolic extract was fractionated from the total oil extract. The seeds were found to contain with $9.25 \%$ moisture content and $8.01 \%$ ash content.

Table 1: Proximate composition of radish seeds.

\begin{tabular}{llll}
$\begin{array}{l}\text { Moisture con- } \\
\text { tent (\%) }\end{array}$ & $\begin{array}{l}\text { Ash content } \\
\text { (\%) }\end{array}$ & $\begin{array}{l}\text { Oil content } \\
\text { (\%) }\end{array}$ & $\begin{array}{l}\text { Methanolic } \\
\text { extract (\%) }\end{array}$ \\
\hline $9.25 \pm 0.11$ & $8.01 \pm 0.46$ & $50.06 \pm 3.11$ & $4.03 \pm 0.16$
\end{tabular}

The symbol \pm shows standard deviation among results of triplicates.

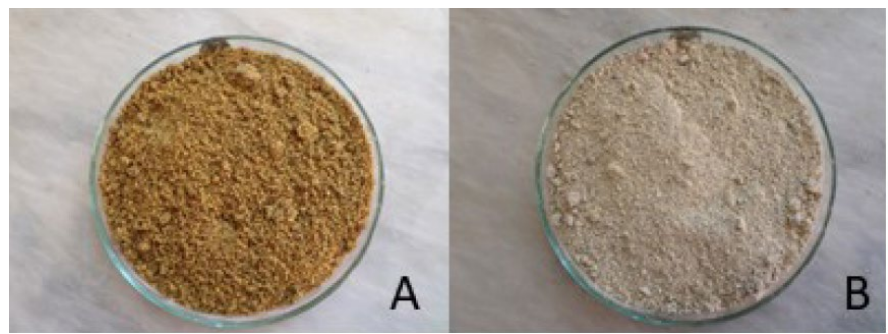

Figure 1: Powdered radish seeds; A) before extraction of oil, B) after extraction of oil.

\section{Phytochemical composition}

Screening of radish seed oil showed presence of most of tested non-volatile compounds. These compounds were comprised of carbohydrates, amino acids and phytometabolites. Phytometabolites are regarded as plant natural products, which serve a defense mechanism against many microorganisms (Bonjar et al., 2004). Raphanin, a glycoside is the main constituent in radish which is responsible for its antimicrobial activity (Duke and Ayensu, 1985; Brown, 1995).

\section{Table 2: Phytochemicals in methanolic fraction of radish} seeds oil.

$\begin{array}{ll}\text { Phytochemicals } & \text { Presence } \\ \text { Phenolic compounds } & - \\ \text { Saponins } & - \\ \text { Alkaloids } & + \\ \text { Tanins } & - \\ \text { Flavonoids } & + \\ \text { Carbohydrates } & + \\ \text { Amino acids } & + \\ \text { Glycosides } & + \\ \text { In the table, + sign denotes presence of the compound while }- \text { sign } \\ \text { indicates absence of the compound or presence in trace amount. }\end{array}$

In the present study, polyphenolic compounds were not detected in the oil while flavonoids test showed 
positive result. The results may indicate that most of phenolic compound might be insoluble in petroleum ether (solvent used to extract radish oil) and flavonoids may present in trace amount or not favor to be detected with $\mathrm{FeCl}_{3}$ test.

\section{Antibacterial activity of Radish seeds oil extract}

The antibacterial study of radish seed oil was performed by agar well diffusion method against the selected bacterial species and their activity aptitudes were qualitatively assessed by presence or absence of inhibition zone. Three different bacterial species were used i.e., (i): Clavibacter sp., (ii): Xanthomonas sp. and (iii): Escherichia coli. Clavibacter and Escherichia coli showed resistant against the oil extract while Xanthomonas sp. did not shown growth on any PDA plate and represented as nil activity. Nil results of Xanthomonas sp. may show that the specie could not resist to the temperature on which it was kept i.e., $37{ }^{\circ} \mathrm{C}$ or PDA might not suitable media for its growth. Some bacteria are naturally resistant to certain antimicrobial components. According to previous studies, it has been found that radish extract is strongly active on many bacterial species (Abdou, 1972; Shukla et al., 2011). The seeds are also believed to contain antibacterial compounds such as raphanin, a glycoside and antimicrobial component (Duke and Ayensu, 1985; Brown, 1995) which is active against E. coli (Shukla et al., 2011; Yeung, 1985). Researchers identified that bacterial pathogens are adapting the ability of resistance by genetic mutation or by acquiring resistance from another bacterium. Resistant rates in $E$. coli are also rapidly growing against many antibiotics (Laupland et al., 2008). Substantial fall in resistant E. coli will occur if sterile food is consumed (Corpet, 1988).

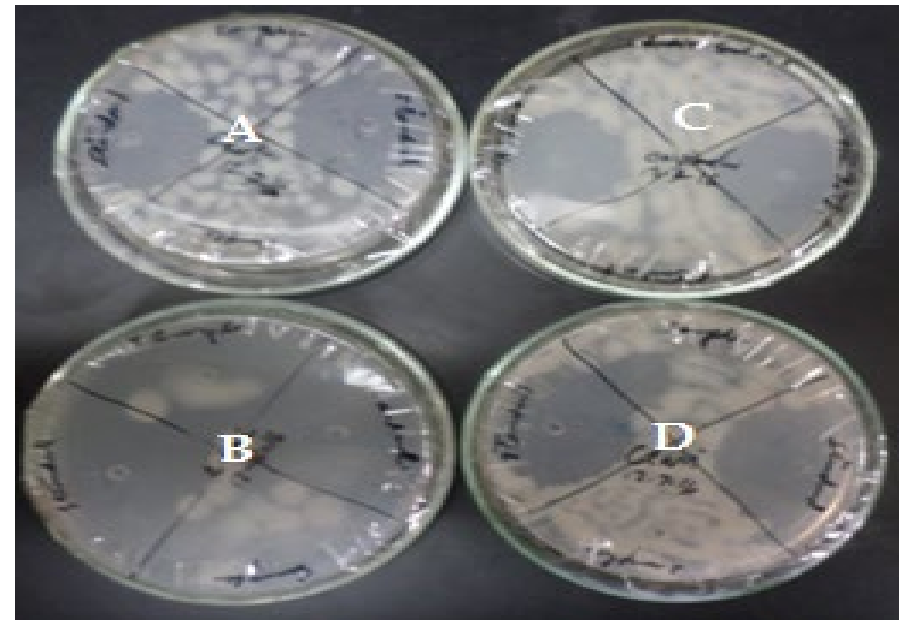

Figure 2: Resistance shown by bacterial species to radish seed oil. ${ }^{*} A$ and $B$ plates show culture of E. coli while $C$ and $D$ show culture of Clavibacter specie.
Table 3: Diameter of zone of inbibition of radish seed oil including positive control on selected bacteria.

$\begin{array}{lll}\text { Sample } & \text { Bacterial specie } & \text { Inhibition zone }(\mathbf{m m}) \pm \text { SD } \\ \begin{array}{l}\text { Radish seed } \\ \text { oil }\end{array} & \text { Clavibacter sp. } & 0 \\ & \begin{array}{l}\text { Escherichia coli } \\ \text { Xanthomonas } s p .\end{array} & 0 \\ & \text { Nil } \\ \text { Amoxicillin } & \text { Clavibacter } p \text {. } & 18.48 \pm 0.08 \\ \text { (Positive } & \text { Escherichia coli } & 18.03 \pm 0.06 \\ \text { control) } & \text { Xanthomonas } \mathrm{sp} . & \mathrm{Nil}\end{array}$

SD is standard deviation among replicated samples.

\section{Conclusions and Recommendations}

Phytochemical tests detected presence of many compounds including carbohydrates, amino acids alkaloids, flavonoids, and glycosides in radish seeds. Presence of these phytometabolites assumed potency of radish seed extract against pathogenic microbes and other human and plant diseases. Antibacterial assay performed against pathogenic bacterial species showed that Clavibacter sp., and E. coli were susceptible to amoxicillin (positive control) by inhibiting approximately $18 \mathrm{~mm}$ in both bacterial species but resistant to radish seed oil. Xanthomonas bacterial sp. did not show any results. Thus, it is concluded that either the used bacterial species are more resistant strains or the oil extract does not possess anti-pathogenic agent against tested bacterial species.

\section{Acknowledgments}

The authors are grateful to the department of Agricultural Chemistry, The University of Agriculture Peshawar, Pakistan for the provision of bacterial culture and availability of laboratory equipment for utilization.

\section{Authors Contribution}

Nadia Khan: Designed and practically performed. Abdul Waheed and Farrukh Siyar Hamid: Supervised the complete experiment.

Naveed Ahmed: Review of literature and correction in final draft.

Zafar Iqbal: Supervised and helped out in extraction of Radish seed oil.

Seemab Ali: Practically performed.

Madiha Bashir: Made draft paper.

Hina Gul: Collection of data. 
References

Abdou, I.A. 1972. Antimicrobial activities of Allium sativum, Allium cepa, Raphanus sativus, Capsicum frutescens, Eruca sativa, Allium kurrat on bacteria. Qualitas Plant. 29-35.

Bonjar, G.H.S., Nik, A.K. and Aghighi, S. 2004. Antibacterial and antifungal survey in plants in indeginous herbal medicine of South east regions of Iran. J. Biol. Sci. 4: 405-412. https:// doi.org/10.3923/jbs.2004.405.412

Brown, D. 1995. Encyclopaedia of Herbs and their Uses, Dorling Kindersley, London, UK.

Caceres, A. 1987. Screening on antimicrobial activity of plants popular in Guatemala for the treatment of dermatomucosal diseases. J. Ethnopharm. 20 : 223-237. https://doi. org/10.1016/0378-8741(87)90050-X

Candido, E.S., Pinto, M.F., Pelegrini, P.B., Lima, T.B., Silva, O.N., Pogue, R., Grossidesa, M.F. and Franco, O.L. 2011. Plant storage proteins with antimicrobial activity: novel insights into plant defense mechanisms. Faseb J. 25: 32903305. https://doi.org/10.1096/f.11-184291

Corpet, D.E. 1988. Antibiotic resistance from food. N. Engl. J. Med. 318(18): 1206-1207. https:// doi.org/10.1056/NEJM198805053181818

Duke, J.A. and Ayensu,E.S. 1985. Medicinal Plants of China. 1st edn. Ref. Publ. Inc., China.

Evans, W.C., Trease and Evans. 2002. Pharmacognosy. 15 th edn. W.B. Sounders and Co., London.

GoP. 2016. Fruits, Vegetables and Condiments Statistics of Pakistan 2014-15. Ministry of Food and Agriculture (Economic wing). Partners available at: http://www.amis.pk.

Gutiérrez R.M.P. and Perez R.L. 2004. Raphanus satious (Radish): their chemistry and biology. Sci. World J. 4 : 811-837. https://doi. org/10.1100/tsw.2004.131

Horwitz, W. 2000. Volume: Official Methods of Analysis, AOAC International: 17th edn.

Idu, M. and Igeleke, C.L. 2012. Antimicrobial Activity and Phytochemistry of Khaya senegalensis Roots. Int. J. Ayur. Herb. Med. 2: 415-422.

Javaid, A. and Bashir, A. 2015. Radish extracts as natural fungicides for management of Fusarium oxysporum F. Sp. Lycopersici, the cause tomato wilt. Pak. J. Bot. 47: 321-324.

Kim, W.K., Kim, J.H., Jeong, D.H., Chun, Y.H., Kim, S.H., Cho, K.J. and Chang, M.J. 2011. Ra- dish (Raphanus satious L. leaf) ethanol extract inhibits protein and $m$ RNA expression of Erb $B$ (2) and $\operatorname{ErbB}(3)$ in MDA-MB-231 human breast cancer cells. Nutr. Res. Pract. 5: 288-293. https://doi.org/10.4162/nrp.2011.5.4.288

Laupland, K.B., Church, D.L., Vidakovich, J., Mucenski, M. and Pitout, J.D. 2008. Community-onset extended-spectrum beta-lactamase (ESBL) producing Escherichia coli: importance of international travel. J. Infect. 57: 441-448. https://doi.org/10.1016/j.jinf.2008.09.034

Lugasi, A., Blazovics, A., Hagymasi, K., Kocsis, I. and Kéry, A. 2005. Antioxidant effect of squeezed juice of black radish (Raphanus sativus L. var niger) in alimentary hyperlipidaemia in rats. Phytoter. Res. 19: 587-591. https://doi. org/10.1002/ptr.1655

Martinez, F.E., Dunford, N.T. and Salas, J.J. 2015. Sunflower: Chemistry, Production, Processing, and Utilization, Elsevier.

Prasad, M.S., Joshi, S., Narendra, K., Nadiya, S.K., Masthani, S.K., Phani, N.P., Satya, A.K. 2015. A comparative study of phytochemical analysis and in vitro antimicrobial activity of three important vegetables from brassicaceae family. Int. J. Res. Ayurveda Pharm. 6:767-772. https://doi. org/10.7897/2277-4343.066143

Rojas, J.J., Ochoa, V.J., Ocampo, S.A. and Munoz, J.F. 2006. Screening for antimicrobial activity of ten medicinal plants used in Colombian folkloric medicine: A possible alternative in the treatment of non-nosocomial infections. BMC Complement Altern Med. 6 : 2. https://doi. org/10.1186/1472-6882-6-2

Seiber, J.N., Coats, J., Duke, S.O. and Gross, A.D. 2014. Biopesticides: State of the Art and Future Opportunities. J. Agric. Food Chem. 62(48): 11613-11619. https://doi.org/10.1021/ jf504252n

Shukla, S., Chatterji, S., Yadav, D.K. and Watal, G. 2011. Antimicrobial efficacy of Raphanus sativus root juice. Int. J. Pharm. Pharma Sci. 3(5) : 89-92.

Sofowora, A. 1993. Medicinal Plants and Traditional Medicine in Africa, Spectrum Books Ltd., Ibadan.

Trease, G.E. and Evans, W.C. 1983. Pharmacognosy. 12th edn. Balliere Tindall, Eastbourne, U.K. Trease, G.E., Evans, W.C. 1989. Pharmacognosy. 13th edn. ELBS London.

Wang, Y., Sun, D., Chen, H., Qian, L. and Xu, P. 
2011. Fatty acid composition and antioxidant activity of tea (Camellia sinensis L.) seed oil extracted by optimized supercritical carbon dioxide. Int. J. Mol. Sci. 12 : 7708-7719. https://doi. org/10.3390/ijms12117708

Yeung, H.C. 1985. Volume: 1 Handbook of Chinese Herbs and Formulas, Inst. Chin. Med. Los Angeles, CA, USA. 